Open Access

\title{
Erratum to: Establishing medical plausibility in the context of orphan medicines designation in the European Union
}

Stelios Tsigkos ${ }^{1 *}$, Segundo Mariz ${ }^{1}$, Jordi Llinares¹, Laura Fregonese' ${ }^{1}$ Stiina Aarum', Frauke Naumann-Winter², Kerstin Westermark ${ }^{3}$ and Bruno Sepodes ${ }^{4}$

\section{Erratum}

After publication of [1] it came to the authors' attention that Frauke Naumann-Winter's name was displayed incorrectly. The correct spelling of their name is included in this erratum.

\section{Author details}

'Orphan Medicines Office, European Medicines Agency, 7 Westferry Circus, Canary Wharf, London E144HB, UK. ${ }^{2}$ Bundesinstitut für Arzneimittel und Medizinprodukte, Kurt-Georg-Kiesinger-Allee 3, Bonn 53175, Germany. ${ }^{3}$ Läkemedelsverket, Dag Hammarskjölds vägen 42, Uppsala 75103, Sweden. ${ }^{4}$ Research Institute for Medicines (iMED.ULisboa), Faculty of Pharmacy, University of Lisbon, Lisboa 1649-003, Portugal.

Received: 17 July 2015 Accepted: 17 July 2015

Published online: 06 October 2015

\section{References}

1. Tsigkos S, Mariz S, Llinares J, Fregonese L, Aarum S, Frauke N, et al. Establishing medical plausibility in the context of orphan medicines designation in the European Union. Orphanet Journal of Rare Diseases. 2014; 9:175.

* Correspondence: Stylianos.Tsigkos@ema.europa.eu

1 Orphan Medicines Office, European Medicines Agency, 7 Westferry Circus, Canary Wharf, London E144HB, UK

Full list of author information is available at the end of the article

\section{Submit your next manuscript to BioMed Central} and take full advantage of:

- Convenient online submission

- Thorough peer review

- No space constraints or color figure charges

- Immediate publication on acceptance

- Inclusion in PubMed, CAS, Scopus and Google Scholar

- Research which is freely available for redistribution

Submit your manuscript at www.biomedcentral.com/submit 